\title{
Development of Improved Iron Fischer-Tropsch Catalysts
}

Quarterly Technical Progress Report for the Period 1 April 1991 - 30 June 1991

Prepared by: Dragomir B. Bukur

Contributors:
X. Lang
L. Nowicki
K. Okabe
H. Robby

\begin{abstract}
Texas A\&M University
Department of Chemical Engineering

College Station, Texas 77843-3122
\end{abstract}

July 19, 1991

Prepared for the Pittsburgh Energy Technology Center, the United States Department of Energy Under Contract No. DE-AC22-89PC89868

V. Udaya Rao, Project Manager (PETC)

"U.S. Department of Energy Patent Clearance not required prior to publication of this document"
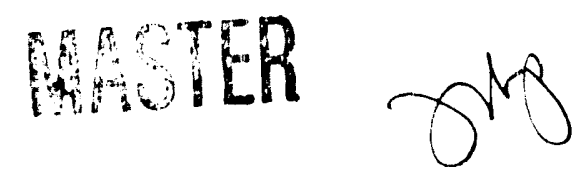
NOTICE

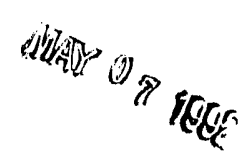

This report was prepared as an account of work sponsored by an agency of the United States Government. Neither the United States nor any agency thereof, nor any of their employees, makes any warranty, expressed or implied, or assumes any legal liability or responsibility of any third party's results of such use of any information, apparatus, product or process disclosed in this report, or represents that its use by such a third party would not infringe privately owned rights.

\section{PATENT STATUS}

U.S./DOE Patent Clearance is not required prior to the publication of this document.

\section{TECHNICAL STATUS}

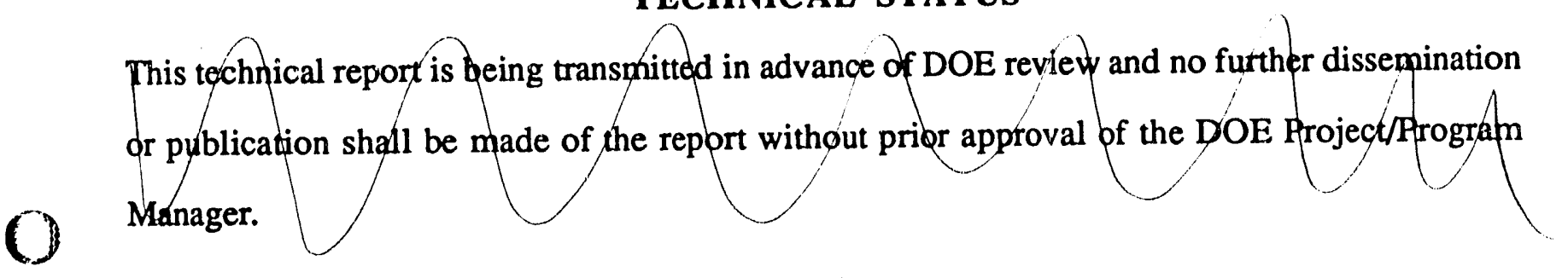




\section{TABLE OF CONTENTS}

- ${ }^{*}$ EXXCUTIVE SUMMARY $\ldots \ldots \ldots \ldots \ldots \ldots \ldots \ldots \ldots \ldots \ldots \ldots$

II. OBJECTIVE AND SCOPE OF WORK $\ldots \ldots \ldots \ldots \ldots \ldots \ldots \ldots \ldots$

III. DETAILED DESCRIPTION OF TECHNICAL PROGRESS $\ldots \ldots \ldots \ldots \ldots 4$

III-1. Task 2. Catalyst Pretreatment Research $\ldots \ldots \ldots \ldots \ldots \ldots \ldots \ldots$

III-2. Task 3. Improved Iron/Silica Catalysts $\ldots \ldots \ldots \ldots \ldots \ldots \ldots \ldots \ldots$

III-2.1 Run FB-1431 with $100 \mathrm{Fe} / 5 \mathrm{Cu} / 4.2 \mathrm{~K} / 16 \mathrm{SiO} 2$ Catalyst $\ldots \ldots \ldots \ldots \ldots$

III-3. Catalyst Characterization $\ldots \ldots \ldots \ldots \ldots \ldots \ldots \ldots \ldots \ldots \ldots \ldots \ldots \ldots \ldots \ldots$

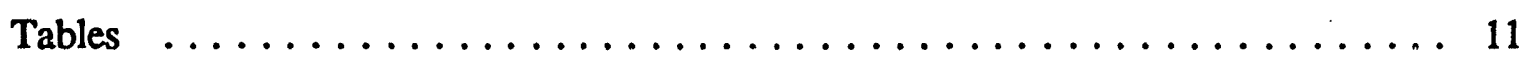

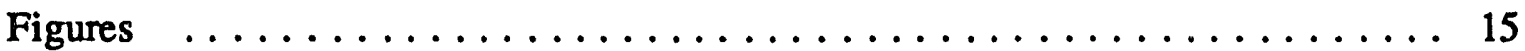

Appendix I. Slurry Reactor Tests of Iron/Silica Catalysts (Not for publication/distribution) $\not 2$ * remone per Cherig tiele ffice 


\section{EXECUTIVE SUMMARY}

Three tests ( 1 fixed bed, and 2 slurry reactor tests) were completed during the reporting period. A precipitated iron catalysts with nominal composition $100 \mathrm{Fe} / 5 \mathrm{Cu} / 4.2 \mathrm{~K} / 16 \mathrm{SiO}_{2}$ was tested in a fixed bed reactor run FB-1431. The catalyst was tested at different process conditions ( 6 mass balances over a period of $175 \mathrm{~h}$ ): $\mathrm{T}=220,235$ and $250^{\circ} \mathrm{C}, \mathrm{P}=1.48$ or $2.96 \mathrm{MPa}, \mathrm{SV}=$ 2 or $4 \mathrm{~N} / / \mathrm{g}$-cat/h and $\mathrm{H}_{2} / \mathrm{CO}$ molar feed ratio of 1 . The $\left(\mathrm{H}_{2}+\mathrm{CO}\right)$ conversion varied between 35 and $67 \%$, and methane selectivity was low: $2.6-3.8 \%$. Catalyst deactivated significantly after exposure to relatively high pressure (2.96 MPa, i.e. $400 \mathrm{psig})$.

Two slurry reactor tests, SA-1371 and SB-0931, of silica containing catalysts lasted 360 and $570 \mathrm{~h}$, respectively. Catalyst deactivation rate in test SA-1371 was rather high $(\sim 3.3 \%$ per day), and the $\left(\mathrm{H}_{2}+\mathrm{CO}\right)$ conversion decreased from an initial value of $83 \%$ to $52 \%$ at the end of the test. Methane selectivity increased with time-on stream (TOS), from 4.6 to $6.4 \%$.

Catalyst tested in run SB-0931, was more stable (deactivation rate of about $1.7 \%$ per day), and more selective towards higher molecular weight hydrocarbons than the catalyst tested in run SA-1371. Process conditions were varied throughout the test, and the $\left(\mathrm{H}_{2}+\mathrm{CO}\right)$ conversion was between 51 and $88 \%$. Hydrocarbon product distribution was within the DOE target, i.e. $\left(C_{1}+C_{2}\right)$ selectivity less than $7.3 \%$, throughout the entire test. Methane selectivity was low, between 2.5 and 3.8\%, whereas selectivity of $\mathrm{C}_{12}{ }^{+}$products was high, $65-70 \%$. In-situ catalyst regeneration was attempted at about $500 \mathrm{~h}$ on stream, resulting in higher catalyst activity (57\% of the initial activity prior to regeneration vs. $66 \%$ after the regeneration).

The work on catalyst characterization has continued during this quarter. Surface areas and pore size distribution were determined by BET method for 8 catalyst samples ( 3 unsupported, and 5 silica containing catalysts) after calcination in air at $300^{\circ} \mathrm{C}$ for $5 \mathrm{~h}$. Surface area varied between $130(100 \mathrm{Fe} / 0.3 \mathrm{Cu} / 0.8 \mathrm{~K})$ and $290 \mathrm{~m} 2 / \mathrm{g}$ (Ruhrchemie catalyst). Used catalyst samples from previous fixed bed and slurry reactor tests were characterized by X-ray diffraction (XRD) and crystalline phases were identified for 12 samples. Crystalline particle size was determined for four 
of these twelve samples by line broadening method, and estimated values were between 300 and $1040 \AA$. Also, the actual elemental composition of 22 synthesized catalysts was determined by atomic absorption (AA). In general, the intended and actual copper contents were in excellent agreement, whereas the actual amounts of potassium determined by AA were somewhat greater than the intended ones (particularly for the silica containing catalysts). Determination of silica content by this method is subject to relatively large errors (uncertainty).

A new fixed bed reactor has been designed, fabricated and tested. This unit will be used for studies of pretreatment effects on the initial state of catalyst. Also, we have designed a sample holder which will prevent the catalyst exposure to air during XRD measurements.

\section{OBJECTIVE AND SCOPE OF WORK}

The objective of proposed research is development of catalysts with enhanced slurry phase activity and better selectivity to fuel range products, through a more detailed understanding and systematic studies of the effects of pretreatment procedures and promoters/binders (silica) on catalyst performance. In order to accomplish this objective, the work shall be divided into several tasks which are described in the following subsections.

\section{Task 1 - Project Management}

Within 60 days of project initiation, the contractor shall prepare and submit to the DOE Project Manager a detailed project work plan covering the entire period of performance of the project. The plan shall present, in detail, all activities that will be performed to successfully complete proposed research and it shall consist of the following: (1) detailed description of the methods and technical approach that shall be used to achieve the objectives of this project; (2) a detailed project schedule for each task or other logical segment of work to be performed; (3) graphs reflecting cumulative estimated costs and person-hour expended by month for each task or other logical segment of work, and for the total project effort; (4) a project work chart showing the key personnel/groups planned to work on each task and percentage of their time devoted to the tasks; and (5) a Work 
Breakdown Structure (WBS) dictionary to establish the framework for contract execution and to report cost schedule and technical performance. All project status, milestone schedule, and cost management reports, as well as topical reports, if any, shall be submitted in accordance with the DOE reporting requirements.

\section{Task 2 - Catalyst Pretreatment Research}

This task is aimed at developing optimal pretreatment conditions for precipitated unsupported (1 catalyst) and supported (or silica containing; $1-2$ ) iron catalysts, and at providing a better understanding of the role of pretreatment on subsequent catalyst activity, selectivity and longevityduring Fischer-Tropsch synthesis (FTS). This shall be accomplished by examining the effect of various activation conditions on physical and chemical properties of the catalyst as well as on catalytic behavior in fixed and slurry bed reactors. Parameters such as type of reductant $(\mathrm{H} 2$ vs. CO vs. syngas), reductant flow rate, temperature and duration shall be studied. Selected catalysts shall be extensively characterized using a variety of physical, chemical and instrumental techniques with the objective to establish correlations between the physical/chemical properties of the catalysts and their observed catalytic behavior during FTS.

\section{Task 3 - Improved Iron Silica Catalyst}

The objective of this task is to determine optimal concentrations of silica and $\mathrm{K} 2 \mathrm{O}$ in a catalyst with composition $100 \mathrm{Fe} / \mathrm{x} \mathrm{Cu} / \mathrm{y} \mathrm{K}_{2} \mathrm{O} / \mathrm{z} \mathrm{SiO}$ (in parts per weight). The effect of $\mathrm{SiO} 2$ and $\mathrm{K} 2 \mathrm{O}$ on catalytic activity, selectivity and stability shall be determined to arrive at promcter/binder concentrations for an improved catalyst performance. The screening tests shall be conducted in fixed bed reactors to obtain preliminary indication of F-T activity and selectivity at different process conditions. Catalysts which show enhanced activity and/or selectivity towards transportation fuels shall be tested in slurry reactors up to 30 days on stream. Selected catalysts shall be extensively characterized, to determine relations between the physico-chemical properties of catalyst and their catalytic behavior during F-T synthesis. 


\section{DETAILED DESCRIPTION OF TECHNICAL PROGRESS}

\section{III-1. Task 2. Catalyst Pretreatment Research}

There have been no catalyst tests conducted related to this task. However, some work was done on characterization of two catalysts (100 Fe/0.3 Cu/0.8 K and Ruhrchemie LP 33/81), which were tested earlier in this contract. Results from these characterization studies can be found in Section III-3 of this report.

We have designed, fabricated and tested a new fixed bed reactor for pretreatment effect studies (1/2 inch OD, $43 / 4$ inch long). This unit was constructed primarily for catalyst characterization studies following catalyst pretreatment in different reducing atmospheres. At the end of a pretreatment, the catalyst bed is purged with helium, and the reactor is sealed in helium atmosphere, at a pressure greater than atmospheric pressure, by closing two values located about 2.5 inches upstream and downstream of the reactor. The unit is then removed, and catalyst enuptied in a glove box in an inert atmosphere. Catalyst samples are placed in vials, and later sealed for future characterization studies. Two samples of the Ruhrchemie catalyst $(-2.5 \mathrm{~g}$ prior to pretreatment) were pretreated in this reactor at $280^{\circ} \mathrm{C}, 3 \mathrm{~N} / / \mathrm{g}$-cat/h for $8 \mathrm{~h}$ in either $\mathrm{H}_{2}$ or $\mathrm{CO}$, and samples were preserved in sealed ampules filled with helium for future characterization studies.

Also, we have designed an $\mathrm{X}$-ray diffraction sample holder which prevents catalyst exposure to air. This will enable us to obtain reliable information on crystalline phases in a catalyst after various pretreatment procedures.

\section{III-2. Task 3. Improved Iron/Silica Catalysts}

Three tests ( 1 screening test in a fixed bed reactor, and two stability tests in a slurry reactor) were completed during the reporting period. Results from these tests are described in detail in section III-2.1 and Appendix I. 


\section{III-2.1 Run FB-1431 with $100 \mathrm{Fe} / 5 \mathrm{Cu} / 4.2 \mathrm{~K} / 16 \mathrm{SiO}_{2}$ Catalyst}

The catalyst $100 \mathrm{Fe} / 5 \mathrm{Cu} / 4.2 \mathrm{~K} / 16 \mathrm{SiO}_{2}$ was tested in run designated FB-1431. The catalyst was ground and sized to 30/60 mesh, and diluted with glass beads of the same mesh size range when loaded to the reactor. Catalyst reduction was performed in-situ, using $\mathrm{CO}$ as the reductant for $12 \mathrm{~h}$ at $280^{\circ} \mathrm{C}$. The run included six mass balances, at 220,235 , and $250^{\circ} \mathrm{C}, 2$ and 4 $\mathrm{N} l /$ g-cat/h, and 1.48 and $2.96 \mathrm{MPa}$. Only a single balance was conducted at high pressure, and all balances were made using synthesis gas with nominal $\left(\mathrm{H}_{2} / \mathrm{CO}\right)$ molar ratio of 1 .

The results of the six mass balances of run FB-1431 are summarized in Table 1. The activity of the $100 \mathrm{Fe} / 5 \mathrm{Cu} / 4.2 \mathrm{~K} / 16 \mathrm{SiO}_{2}$ catalyst was high but lower than the activity of the 100 $\mathrm{Fe} / 5 \mathrm{Cu} / 4.2 \mathrm{~K} / 8 \mathrm{SiO}_{2}$ catalyst tested in run FA-63-0418 (Technical Progress Report 1 January $31 \mathrm{March}, 1988$; DE-AC22-85PC80011). The $\left(\mathrm{H}_{2}+\mathrm{CO}\right)$ conversion at $220^{\circ} \mathrm{C}(1.48 \mathrm{MPa}, 2 \mathrm{~N} l / \mathrm{g}-$ cat.h, balance 4) was $43.5 \%$, increasing to $67.2 \%$ at $235^{\circ} \mathrm{C}$ (balance 1) at the same pressure and space velocity. At the same nominal conditions, the catalyst containing 8 parts $\mathrm{SiO}_{2}$ achieved $62.1 \%\left(220^{\circ} \mathrm{C}\right)$ and $76.7 \%\left(235^{\circ} \mathrm{C}\right)\left(\mathrm{H}_{2}+\mathrm{CO}\right)$ conversions. Doubling the space velocity to $4 \mathrm{~N} / \mathrm{g}-$ cat.h gave $\left(\mathrm{H}_{2}+\mathrm{CO}\right)$ conversions of 44.2 and $63.0 \%$ at 235 and $250^{\circ} \mathrm{C}$, respectively. A repeat of conditions used during balance $1\left(235^{\circ} \mathrm{C}, 1.48 \mathrm{MPa}, 2 \mathrm{Nl} / \mathrm{g}\right.$-cat $\left.\mathrm{h}\right)$ was made in balance 5 , and the $\left(\mathrm{H}_{2}+\mathrm{CO}\right)$ conversion dropped from $67.2 \%$ to $59.5 \%$. During balance 6 , the pressure was increased to $2.96 \mathrm{MPa}$, holding (P/SV) constant, and the $\left(\mathrm{H}_{2}+\mathrm{CO}\right)$ conversion was $35.1 \%$. This conversion is much lower in comparison with the $59.5 \%$ conversion in balance 5 , and indicates that the catalyst deactivated markedly at high pressure. The weight percent methane in the hydrocarbon products was low at all conditions tested. The hydrocarbon distribution at $220^{\circ} \mathrm{C}$ (balance 4) was $2.56\left(\mathrm{CH}_{4}\right), 15.4\left(\mathrm{C}_{2}-\mathrm{C}_{4}\right), 25.5\left(\mathrm{C}_{5}-\mathrm{C}_{11}\right)$, and $56.6 \%\left(\mathrm{C}_{12}{ }^{+}\right)$. Raising the temperature to $235^{\circ} \mathrm{C}$ (balance 1) increased the methane and $\mathrm{C}_{2}-\mathrm{C}_{4}$ fractions to $3.3 \%$ and $16.0 \%$ respectively. The methane and $\mathrm{C}_{2}-\mathrm{C}_{4}$ fractions increased further, at $250^{\circ} \mathrm{C}$ (balance 3) to $3.8 \%$ and $17.1 \%$ respectively. No significant effect was seen with gas space velocity ( 2 and $4 \mathrm{~N} / \mathrm{g}$-cat-h) at 
$235^{\circ} \mathrm{C}, 1.48 \mathrm{MPa}$ (balances 1 and 2) on the weight percent hydrocarbon distribution. Hydrocarbon selectivities obtained with this catalyst were similar to those obtained earlier with the catalyst containing 8 parts of $\mathrm{SiO}_{2}$ per 100 parts of iron.

Carbon number distribution (up to $\mathrm{C}_{50}$ ) of products collected during the first mass balance is shown in Figure 1. Exprimental data are represented well by a three parameter model of Huff and Satterfield (double alpha phenomena).

\section{III-2.2 Run SB-0931}

Results from this test contain potentially patentable information and are discussed in a separate section of this report (Appendix I), which is not intended for publication/distribution.

\section{III-2.3 Run SA-1371}

Results from this test contain potentially patentable information and are discussed in a separate section of this report (Appendix I), which is not intended for publication/distribution.

\section{III-3. Catalyst Characterization}

During the current reporting period, we have completed the elemental analysis of all of the precipitated iron catalysts that will be investigated during this project. We have also continued our catalyst characterization experiments, including surface area and pore size distribution measurements, and x-ray diffraction (XRD) analysis of calcined and used samples. The following sections contain detailed descriptions of progress in each of these areas.

\section{Elemental Analysis of Catalysts}

Each calcined sample (ca. $0.1 \mathrm{~g}$ ) was prepared for analysis by dissolution in $10 \mathrm{ml}$ of concentrated $\mathrm{HCl}$, followed by dilution with distilled water to $100 \mathrm{ml}$. The sample solutions were further diluted, and iron, copper, and potassium contents were determined by atomic absorption (AA). Silicon content of the samples was determined in the following two ways: 
(1) Determination by Calculation (Indirect Determination)

By assuming that the elements are in the form of $\mathrm{Fe}_{2} \mathrm{O}_{3}, \mathrm{CuO}$, and $\mathrm{K}_{2} \mathrm{CO}_{3}$, the weight of $\mathrm{SHO}_{2}^{-}\left(\mathrm{W}_{\mathrm{SiO}_{2}}\right)$ is given by

$$
\begin{aligned}
\mathrm{W}_{\mathrm{SiO}_{2}} & =\mathrm{W}_{\mathrm{o}}-\mathrm{W}_{\mathrm{Fe}} \times \frac{1}{2} \times \frac{\mathrm{Fe}_{2} \mathrm{O}_{3}}{\mathrm{Fe}}-\mathrm{W}_{\mathrm{Cu}} \times \frac{\mathrm{CuQ}}{\mathrm{Cu}}-\mathrm{W}_{\mathrm{K}} \times \frac{1}{2} \times \frac{\mathrm{K}_{2} \mathrm{CO}_{3}}{\mathrm{~K}} \\
& =\mathrm{W}_{\mathrm{o}}-1.43 \mathrm{~W}_{\mathrm{Fe}}-1.25 \mathrm{~W}_{\mathrm{Cu}}-1.77 \mathrm{~W}_{\mathrm{k}}
\end{aligned}
$$

where $W_{0}$ is the weight of the sample, and Wi's are the weight of elements determined by AA.

(2) Direct IDetermination

Each sample (ca. 0.1 or $0.2 \mathrm{~g}$ ) was dissolved in concentrated HF ( $1 \mathrm{ml}$ or $2 \mathrm{ml}$ ), and diluted with distilled water to $50 \mathrm{ml}$. The silicon contents in the solution were determined directly by AA.

The results are summarized in Table 2. Values for copper and potassium levels ( $x$ and $y$ ) in each catalyst are reported in part by weight of metals relative to 100 parts by weight of iron; whereas the value for silica (z), in part by weight of silicon oxide relative to 100 parts by weight of iron. With only a few exceptions, the analyzed copper contents of all catalysts are very close to the nominal values. Most of potassium analyses are generally higher than predicted, especially in the cases of catalysts containing silica. Although the silica contents fluctuated from the expected values, because of relatively large experimental errors, the agreement between actual and expected values was within experimental errors.

\section{Surface Area}

Surface areas and pore volumes were measured by physical adsorption of $\mathrm{N}_{2}$ at $77 \mathrm{~K}$, and values obtained are listed in Table 3. Surface area and pore volume of $100 \mathrm{Fe} / 0.3 \mathrm{Cu} / 0.8 \mathrm{~K}$ catalyst decreased slightly after calcination. With the increase of promoters $(100 \mathrm{Fe} / 5 \mathrm{Cu} / 4.2 \mathrm{~K})$ the surface area increased from 130 to $180 \mathrm{~m}^{2} / \mathrm{g}$, and pore volume decreased from 0.33 to 0.24 $\mathrm{cc} / \mathrm{g}$, suggesting that the promoters (copper and potassium) decreased the particle size of iron oxide by filling the grain boundaries in the catalyst. The addition of silica increased both surface area and pore volume of the catalysts $100 \mathrm{Fe} / 5 \mathrm{Cu} / 4.2 \mathrm{~K} / \mathrm{zSiO}_{2}(\mathrm{z}=8,16,24,40)$. Surface areas of silica 
containing catalysts were similar $\left(220-260 \mathrm{~m}^{2} / \mathrm{g}\right)$, as well as the pore volumes of catalysts with $\mathrm{z} \geq$ 16. $(0.68-0.71 \mathrm{cc} / \mathrm{g})$. However, the catalyst containing 8 parts of $\mathrm{SiO}_{2}$ had much smaller pore volume $(0.36 \mathrm{cc} / \mathrm{g})$ than the other silica containing catalysts. A part of the increase may be ascribed to a decrease in the particle size of iron oxide, whereas the remainder is due to presence of the porous silica. Similar trends were observed with $100 \mathrm{Fe} / 3 \mathrm{Cu} / 4 \mathrm{~K} / z \mathrm{SiO}_{2}$ catalysts $(\mathrm{z}=8,16)$.

\section{Pore Size Distribution}

Differential pore volume distribution obtained by $\mathrm{N}_{2}$ adsorption described above are illustrated in Figures 2 to 4 . A shift of peak maximum from 53 to $65 \AA$ was observed after calcination (Fig. 2 (a) and (b)). The shift is in agreement with observed decreases in surface area and pore volume. The presence of additional promoters (Fig. 2. (c)) gave smaller pore diameter (ca. $38 \AA$ ), corresponding to an increase in surface area.

With the addition of silica to $100 \mathrm{Fe} / 5 \mathrm{Cu} / 4.2 \mathrm{~K}$ catalyst, peak maximum of the pore size distribution shifted below the detection limit of this technique $(\sim 14 \AA)$, and another broad peak appeared in the larger pore diameter range (Fig. 3). The broad peak changed the shape with variations in the silica content, suggesting that this peak is due to silica. The similar distribution was observed with $100 \mathrm{Fe} / 3 \mathrm{Cu} / 4 \mathrm{~K} / \mathrm{zSiO}_{2}$ catalysts $(z=8,16)$, as shown in Fig. 4.

\section{X-Ray Diffraction Results}

During the present reporting period, the phases of used catalysts from earlier fixed bed and slurry reactor tests were identified by X-ray diffraction (XRD), and for some catalysts the crystalline sizes were determined by line broadening method.

Figure 5 shows XRD patterns of calcined and used $100 \mathrm{Fe} / 0.3 \mathrm{Cu} / 0.8 \mathrm{~K}$ catalyst. The calcined catalyst showed pattern typical of hematite $\left(\mathrm{Fe}_{2} \mathrm{O}_{3}\right)$. The XRD patterns of the used catalyst after reduction with $\mathrm{H}_{2}$ at $250^{\circ} \mathrm{C}$ are depicted in Fig. 6 (b) and (c). The used catalyst from top part of the reactor (Fig. 5b) showed peaks of metallic iron as well as peaks of Fe-carbide(s), 
magnetite $\left(\mathrm{Fe}_{3} \mathrm{O}_{4}\right)$ and wax (the reaction product). On the contrary, the XRD pattern of the used catalyst from bottom part of the reactor (Fig. 5c) indicates that the iron carbide(s) is the major phase present. The result indicates that the reaction environment (gas phase composition) has significant effect on the bulk phase composition of the catalyst. The XRD pattern of used catalyst reduced with $\mathrm{CO}$ at $280^{\circ} \mathrm{C}$ (Fig. 5d) showed more intensive peaks of $\mathrm{Fe}_{3} \mathrm{O}_{4}$ and $\mathrm{FeCO}_{3}$ phases as well as wax than the used catalyst reduced with $\mathrm{H}_{2}$. The fact that $\mathrm{CO}$ reduction results in greater proportion of $\mathrm{Fe}_{3} \mathrm{O}_{4}$ relative to $\mathrm{Fe}$-carbide(s) in the used catalyst, is in agreement with the results reported previously for $100 \mathrm{Fe} / 5 \mathrm{Cu} / 4.2 \mathrm{~K} / \mathrm{zSiO}_{2}$ catalysts $(\mathrm{z}=8,40)$.

Figure 6 shows XRD patterns in slow scan of $100 \mathrm{Fe} / 0.3 \mathrm{Cu} / 0.8 \mathrm{~K}$ catalysts (a) after calcination, (b) after reduction with $\mathrm{H}_{2}$ followed by reaction (from the top part of the reactor), and (c) after reduction with $\mathrm{CO}$ followed by reaction. From the line broadening of the peaks corresponding to $\mathrm{Fe}_{2} \mathrm{O}_{3} \mathrm{~d}(104)$ and $\mathrm{d}(110)$ spacings in calcined catalyst, the crystallite sizes are estimated at $220 \AA$ and $370 \AA$, respectively (Table 4). The line width of peak of Fe $d(110)$ spacing in used catalyst (Fig. 6b) showed that the crystallite size of Fe was $320 \AA$, which was almost the same as the original $\mathrm{Fe}_{2} \mathrm{O}_{3}$ crystallite size. The width of peaks of $\mathrm{Fe}_{3} \mathrm{O}_{4}$ in used catalyst reduced with $\mathrm{CO}$ (Fig. $6 \mathrm{c}$ ) was too sharp to estimate the crystallite size, indicating high crystallinity.

Figure 7 shows XRD patterns of used Ruhrchemie catalyst, reduced with $C O$, after different time on stream (TOS). Although the longer reaction time resulted in more intensive peaks of wax (a reaction product) and relatively less intensive peaks of $\mathrm{Fe}_{3} \mathrm{O}_{4}$, there is no evidence of formation of $\mathrm{Fe}$-carbide(s) in spite of long duration of the test indicating stability of the $\mathrm{Fe}_{3} \mathrm{O}_{4}$ phase in the catalyst.

Figure 8 shows XRD patterns of used catalysts from slurry reactor tests. The main phases of iron in all catalysts were $\mathrm{Fe}_{3} \mathrm{O}_{4}$ and $\mathrm{Fe}$-carbide(s). Catalysts reduced with $\mathrm{H}_{2}$ also contained some $\mathrm{FeCO}_{3}$. The similarity of phases present in used catalysts, in spite of the use of different reduction conditions is in contrast to results obtained in fixed bed reactor tests. In the latter case 
the $\mathrm{CO}$ reduction gave rise to $\mathrm{F}_{83} \mathrm{O}_{4}$, and $\mathrm{H}_{2}$ reviuction resulted in $\mathrm{Fe}$-carbide(s) as the main phase in used catalysts.

Crystalline sizes of $\mathrm{Fe}_{3} \mathrm{O}_{4}$ in the used catalysts from slurry reactor tests were estimated from the line broadening of $\mathrm{Fe}_{3} \mathrm{C}_{4}, \mathrm{~d}(311)$ peak, and are listed in Table 4. No simple relation between the size and the catalyst compcsition was obtained.

() 


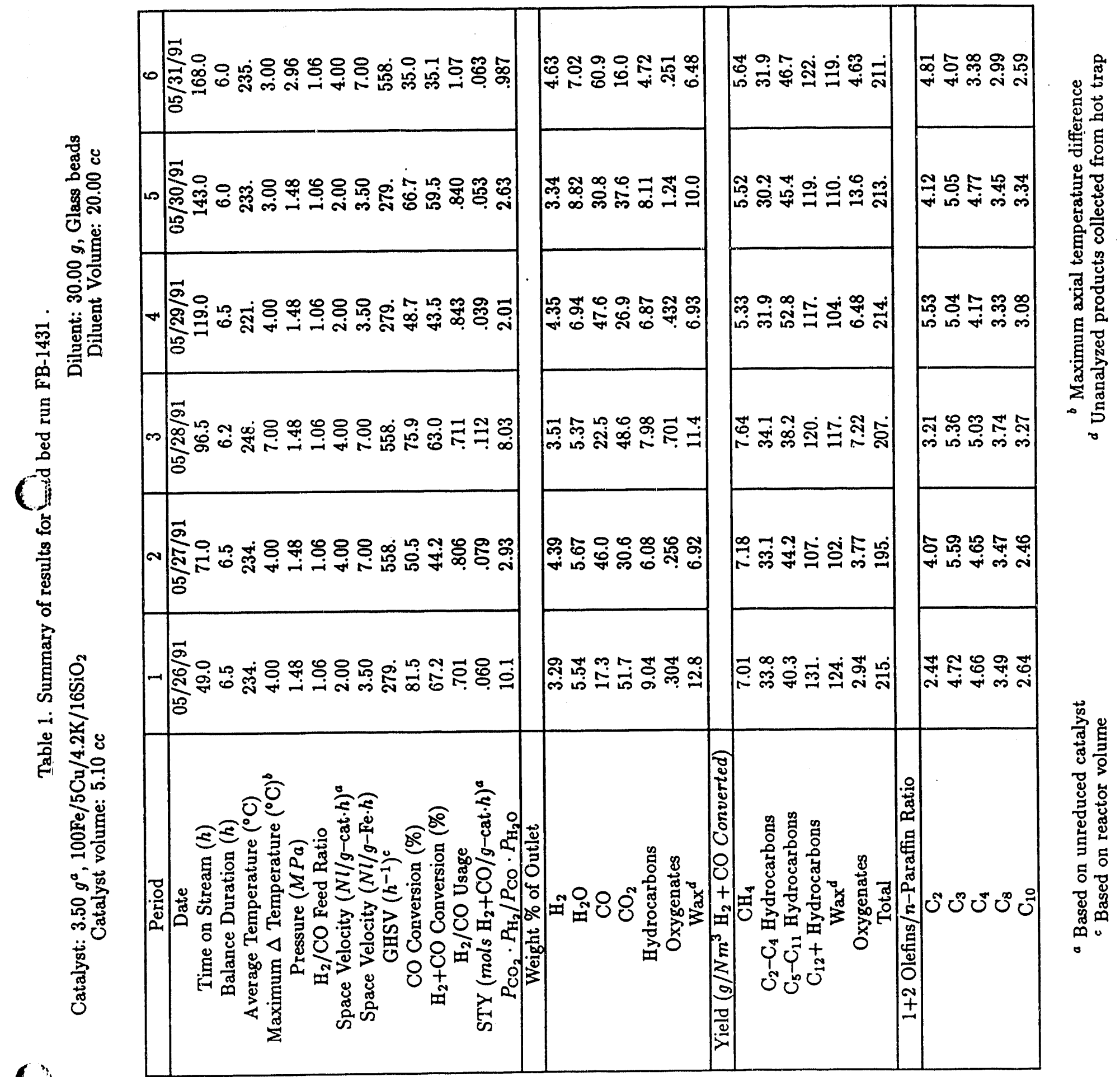




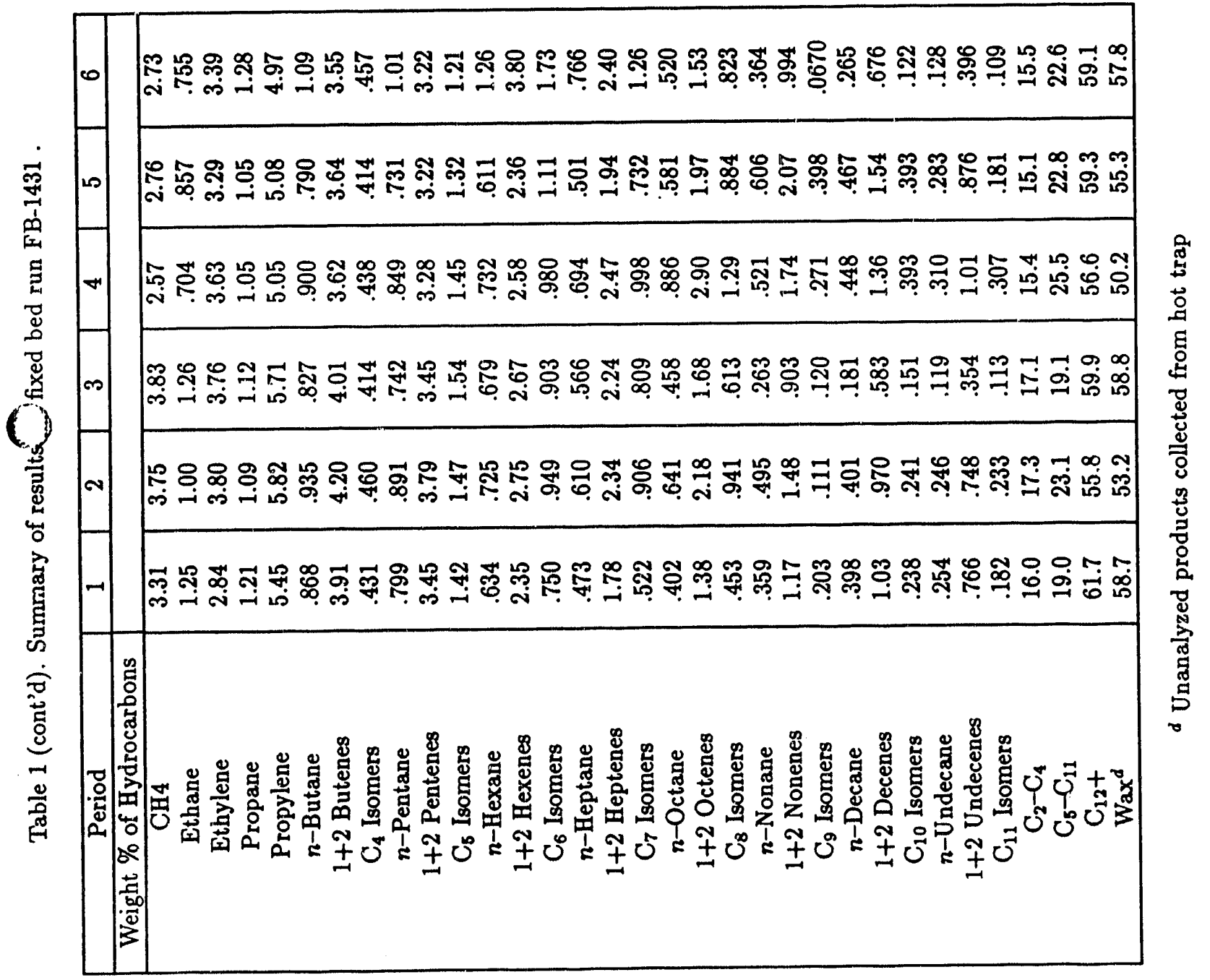


Table 2. Catalyst Composition Determined by Atomic Absorption

\begin{tabular}{|c|c|c|c|c|c|}
\hline $\begin{array}{l}\text { Nominal Composition } \\
\text { loofe/xCu/yk/zSiO }\end{array}$ & $\begin{array}{l}\text { Sample } \\
\text { Code }\end{array}$ & $x$ & $\begin{array}{c}\text { Actual co } \\
y\end{array}$ & $\begin{array}{c}\text { mposition } \\
z^{* 11}\end{array}$ & $z^{* 21}$ \\
\hline $100 \mathrm{Fe} / 0.3 \mathrm{Cu} / 0 . \mathrm{BH}$ & $00308-1$ & $0.27 \pm 0.03$ & $0.75 \pm 0.11$ & & \\
\hline 100Fe/0.3Cu/0.8K & $00308-2$ & $0.29 \pm 0.03$ & $0.77 \pm 0.12$ & & \\
\hline $100 \mathrm{Fe} / 0.30 \mathrm{U} / 0,8 \mathrm{~K}$ & $00308-3$ & $0.33 \pm 0.03$ & $0.84 \pm 0.10$ & & \\
\hline $100 \mathrm{FE} / 0.30 \mathrm{CH} / 1.0 \mathrm{~K}$ & 0.0310 & $0.32 \pm 0.03$ & $1.30 \pm 0.16$ & & \\
\hline $100 F E / 5 C U / 4.2 K$ & 55042 & $4.4 \pm 0.4$ & $4.9 \pm 0.6$ & & \\
\hline $100 \mathrm{Fe} / 3 \mathrm{Cu} / \mathrm{BSi} \mathrm{O}_{2}$ & 53008 & $3.2 \pm 0.3$ & $0.27 \pm 0.03$ & $12.2 \pm 7.4$ & \\
\hline $100 \mathrm{Fe} / 3 \mathrm{CU} / \mathrm{gK} / \mathrm{BSi} \mathrm{O}^{2}$ & 53208 & $3.2 \pm 0.3$ & $2.3 \pm 0.3$ & $11.4 \pm 7.4$ & $13.0 \pm 3.2$ \\
\hline $100 \mathrm{Fe} / \exists \mathrm{Cu} / \mathrm{Br} / \mathrm{BSi} \mathrm{D}^{2}$ & 53908 & $3.3 \pm 0.3$ & $4.5 \pm 0.5$ & $13.9 \pm 7.5$ & \\
\hline $100 \mathrm{Fe} / 3\left[\mathrm{Lu} / 4 \mathrm{k} / \mathrm{gsi} \square_{2}\right.$ & 53408 & $3.1 \pm 0.3$ & $4.7 \pm 0.6$ & $9.5 \pm 7.8$ & $7.7 \pm 2.4$ \\
\hline $100 \mathrm{Fe} / 5 \mathrm{Cu} / 4.2 \mathrm{~K} / 85 \mathrm{iO} 2$ & \#63 & 5.1 & 4 & & 7.8 \\
\hline 10OFE:3CU/16SIOZ & 53016 & $3.1 \pm 0.3$ & $0.31 \pm 0.04$ & $18.6 \pm 7.4$ & \\
\hline 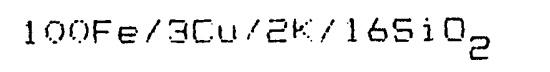 & $53216-1$ & $3.2 \pm 0.3$ & $3.5 \pm 0.4$ & $16.6 \pm 7.4$ & \\
\hline $100 \mathrm{Fe} / 3 \mathrm{CH} / \mathrm{LH} / 16 \mathrm{SiO} \mathrm{O}_{2}$ & $53216-2$ & $3.1 \pm 0.3$ & $2.6 \pm 0.3$ & $17.6 \pm 7.6$ & $22.8 \pm 5.6$ \\
\hline $100 \mathrm{Fe} / 3 \mathrm{Cu} / 4.2 K / 165 \mathrm{~s} \mathrm{D}_{2}$ & $53416-1$ & $3.2 \pm 0.3$ & $6.7 \pm 0.8$ & $13.8 \pm 7.6$ & \\
\hline $100 \mathrm{Fe} / 3 \mathrm{Cu} / 4 \mathrm{~K} / 165 \mathrm{~s} \mathrm{Q}_{2}$ & $53416-2$ & $3.0 \pm 0.3$ & $6.7 \pm 0.7$ & $11.9 \pm 7.7$ & $20.2 \pm 4.9$ \\
\hline $100 \mathrm{Fe} / 3 \mathrm{Cu} / 66 / 165 \mathrm{iO}$ & 53616 & $3.0 \pm 0.3$ & $5.1 \pm 0.6$ & $13.0 \pm 7.5$ & $20.4 \pm 5.0$ \\
\hline $100 \mathrm{Fe} / 50 \mathrm{Cu} / 165 \mathrm{iO}$ & $55016-2$ & $5.1 \pm 0.5$ & $0.56 \pm 0.07$ & $15.6 \pm 7.5$ & \\
\hline $100 \mathrm{Fe} / 5 \mathrm{Cu} / 4.2 \mathrm{~K} / 16 \mathrm{SiO}$ & $55416-1$ & 4.5 & 4.8 & & 17.9 \\
\hline 100FE/SCu/4.2K/16sioz & $55416-2$ & $5.6 \pm 0.5$ & $6.3 \pm 0.8$ & $18.5 \pm 7.7$ & \\
\hline $100 \mathrm{Fe} / 50 \mathrm{Cu} / 249 \mathrm{i} \mathrm{O}_{2}$ & 55024 & $5.0 \pm 0.5$ & $1.40 \pm 0.17$ & $22.1 \pm 7.4$ & \\
\hline $100 \mathrm{Fe} / 5 \mathrm{Cu} / 4 \mathrm{k} / 245 \mathrm{iO} \mathrm{O}_{2}$ & $55424-2$ & $5.2 \pm 0.5$ & $6.6 \pm 0.8$ & $20.6 \pm 7.6$ & \\
\hline $100 \mathrm{Fe} / 5 \mathrm{Cu} / \mathrm{bH} / 24 \mathrm{sin} \mathrm{C}$ & 5.56? & $5.1 \pm 0.5$ & $9.1 \pm 0.7$ & $24.2 \pm 7.7$ & $27.7 \pm 6.8$ \\
\hline $100 \mathrm{Fe} / 5 \mathrm{Cu} / \mathrm{gk} / 24 \mathrm{SiO} \mathrm{Z}$ & 55824 & $5.1 \pm 0.5$ & $10.2 \pm 1.2$ & $24.7 \pm 7.7$ & $30.7 \pm 7.5$ \\
\hline $100 \mathrm{FE} / 5 \mathrm{Cu} / 4 \mathrm{k} / 25 \mathrm{SiO} \mathrm{O}_{2}$ & Ruhrchemie & $5.3 \pm 0.5$ & $5.6 \pm 0.7$ & $70.3 \pm 7.6$ & \\
\hline $100 \mathrm{Fe} / 5 \mathrm{Cu} / 4.2 \mathrm{~K} / 40 \mathrm{SiO} \mathrm{z}$ & $\$ 63.2$ & 4.2 & 6.2 & & 40.3 \\
\hline
\end{tabular}

*1) Estimated by calculation, by determining contents of $\mathrm{Fe}$, Cu, and $k$ and by assuming that the remainder is $5 i 0{ }^{*}$

*2) Direct deterinination of $\mathrm{SiO}_{2}$, by dissolving the sample in HF. 
Table 3. Surface Area and Pore Volume

\begin{tabular}{|c|c|c|c|}
\hline Nominal Composition & Surface Area & Pore Volume & Remarks \\
\hline $100 \mathrm{Fe} / 0.3 \mathrm{Cu} / 0.8 \mathrm{~K}$ & $190 \mathrm{~m}^{2} / \mathrm{g}$ & $0.36 \mathrm{cc} / \mathrm{g}$ & as-prepared \\
\hline $100 \mathrm{Fe} / 0.3 \mathrm{Cu} / 0.8 \mathrm{~K}$ & 130 & 0.33 & calcined \\
\hline $100 \mathrm{Fe} / 5 \mathrm{Cu} / 4.2 \mathrm{~K}$ & 180 & 0.24 & calcined \\
\hline $100 \mathrm{Fe} / 5 \mathrm{Cu} / 4.2 \mathrm{~K} / 8 \mathrm{SiO}_{2}$ & 250 & 0.36 & calcined \\
\hline $100 \mathrm{Fe} / 5 \mathrm{Cu} / 4.2 \mathrm{~K} / 16 \mathrm{SiO}_{2}$ & 257 & 0.68 & calcined \\
\hline $100 \mathrm{Fe} / 5 \mathrm{Cu} / 4 \mathrm{~K} / 24 \mathrm{SiO}_{2}$ & 222 & 0.68 & calcined \\
\hline $100 \mathrm{Fe} / 5 \mathrm{Cu} / 4.2 \mathrm{~K} / 40 \mathrm{SiO}_{2}$ & 238 & 0.71 & calcined \\
\hline Ruhrchemie catalyst $\left(100 \mathrm{Fe} / 5 \mathrm{Cu} / 4 \mathrm{~K} / 25 \mathrm{SiO}_{2}\right)$ & 289 & 0.62 & calcined \\
\hline $100 \mathrm{Fe} / 3 \mathrm{Cu} / 4 \mathrm{~K} / 8 \mathrm{SiO}_{2}$ & 225 & 0.59 & calcined \\
\hline $100 \mathrm{Fe} / 3 \mathrm{Cu} / 4 \mathrm{~K} / 16 \mathrm{SiO}_{2}$ & 245 & 0.65 & calcined \\
\hline
\end{tabular}

Table 4. Crystalline Size Determined by XRD

\begin{tabular}{lllc}
\hline \hline Sample No. & \multicolumn{1}{c}{ Nominal Composition } & Phase* & Crystalline Size $(\AA)$ \\
\hline \hline CO308-3 & $100 \mathrm{Fe} / 0.3 \mathrm{Cu} / 0.8 \mathrm{~K}$ (calcined) & $\mathrm{Fe}_{2} \mathrm{O}_{3}$ & $220-370$ \\
$\mathrm{FB}-3480$ (top) & $100 \mathrm{Fe} / 3 \mathrm{Cu} / 0.8 \mathrm{~K}$ (used) & $\mathrm{Fe}$ & 320 \\
$\mathrm{SB}-0931$ & $100 \mathrm{Fe} / 3 \mathrm{Cu} / 4 \mathrm{~K} / 8 \mathrm{SiO}_{2}$ (used) & $\mathrm{Fe} 3 \mathrm{O}_{4}$ & 470 \\
SB-0261 & $100 \mathrm{Fe} / 3 \mathrm{Cu} / 4.2 \mathrm{~K} / 16 \mathrm{SiO}$ (used) & $\mathrm{Fe}_{3} \mathrm{O}_{4}$ & 1040 \\
SA-99-0888 & Ruhrchemie catalyst (used) & $\mathrm{Fe}_{3} \mathrm{O}_{4}$ & 370 \\
\hline
\end{tabular}

"Phase of which crystalline size was determined by XRD line broadening. 


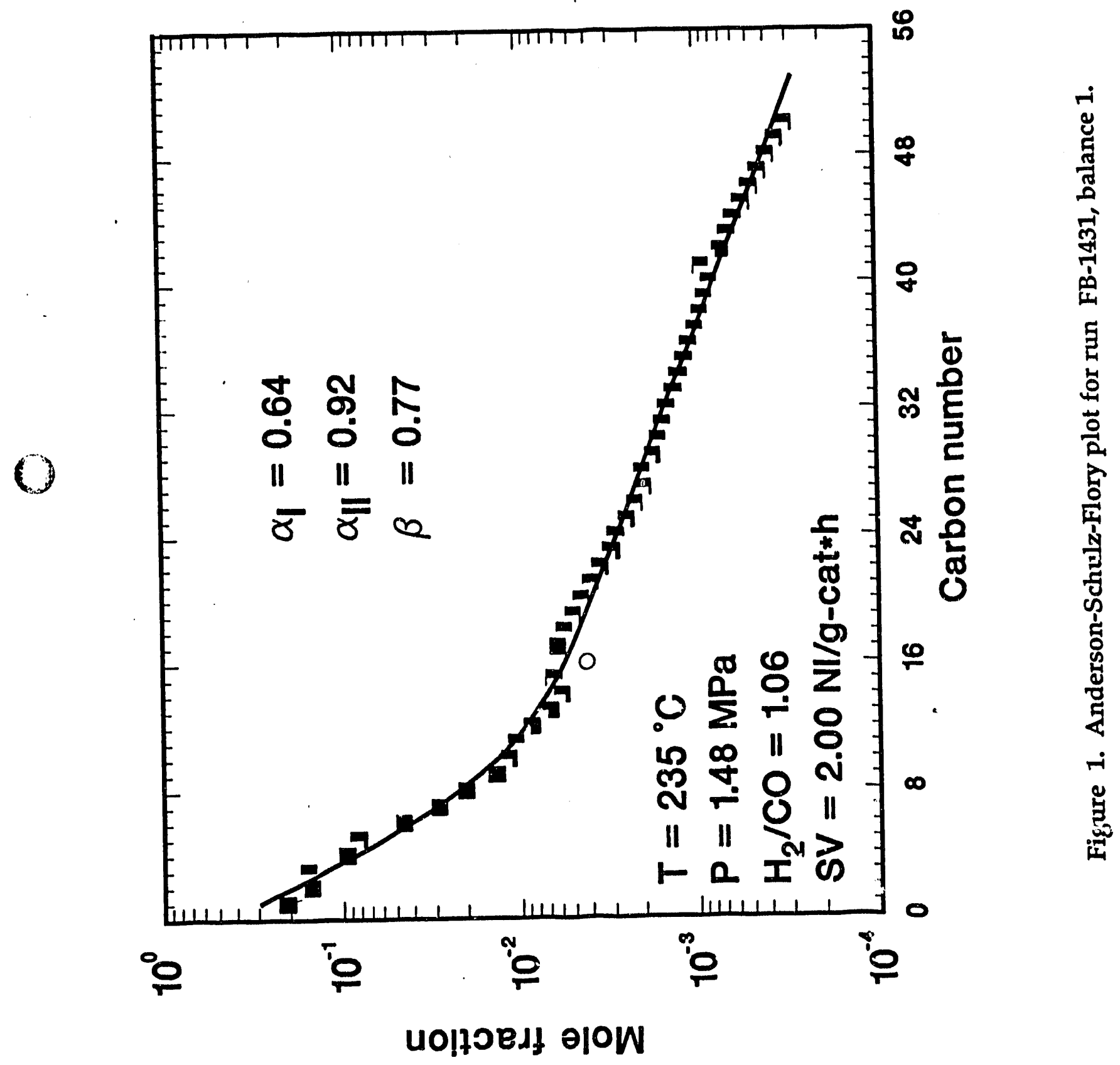




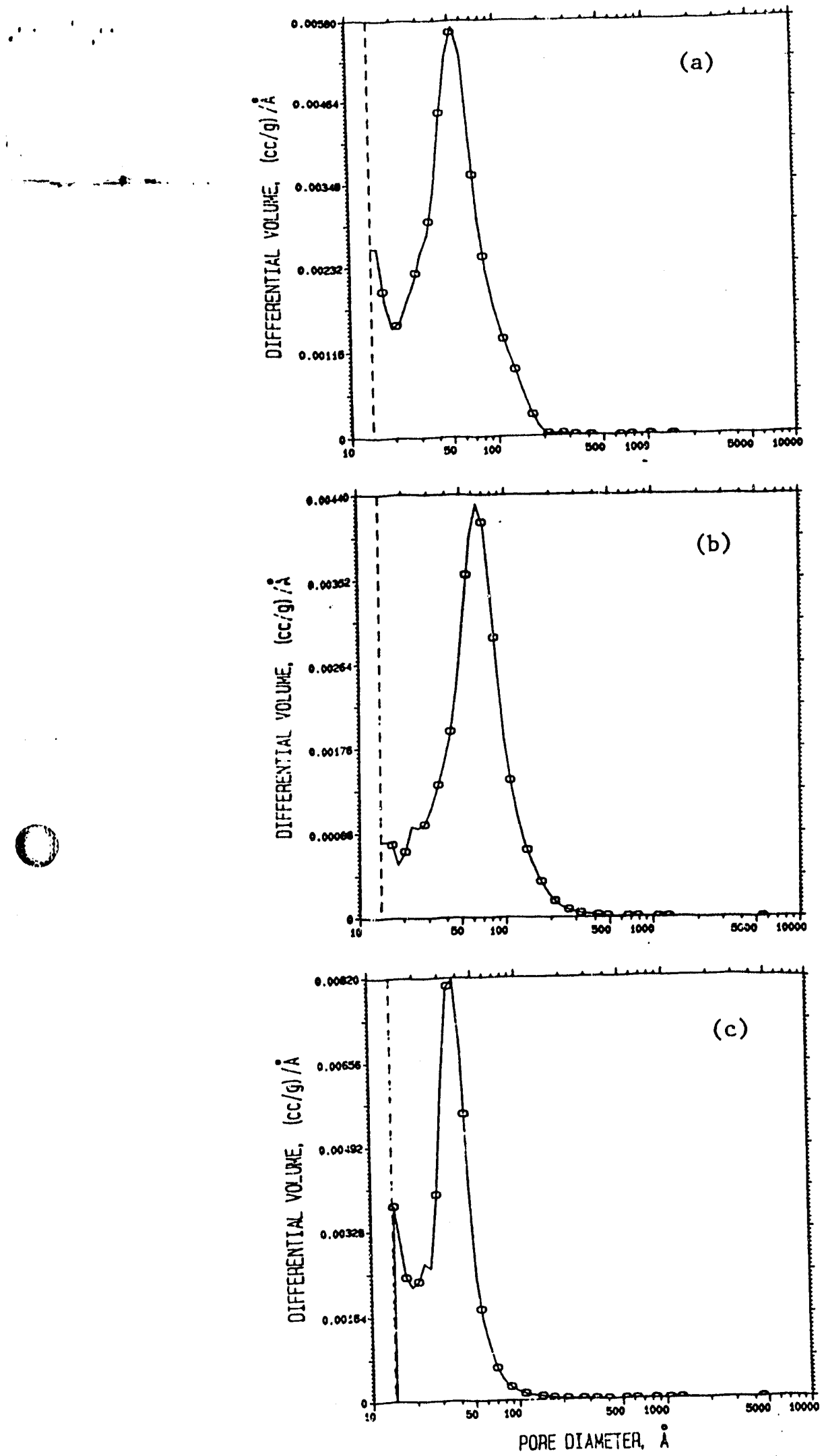

Fig. 2. Differential pore volume distribution of (a) as-prepared $100 \mathrm{Fe} / 0.3 \mathrm{Cu} / 0.8 \mathrm{~K}$ catalyst,

(b) calcined $100 \mathrm{Fe} / 0.3 \mathrm{Cu} / 0.8 \mathrm{~K}$ catalyst, and (c) calcined $100 \mathrm{Fe} / 5 \mathrm{Cu} / 4.2 \mathrm{~K}$ catalyst. 

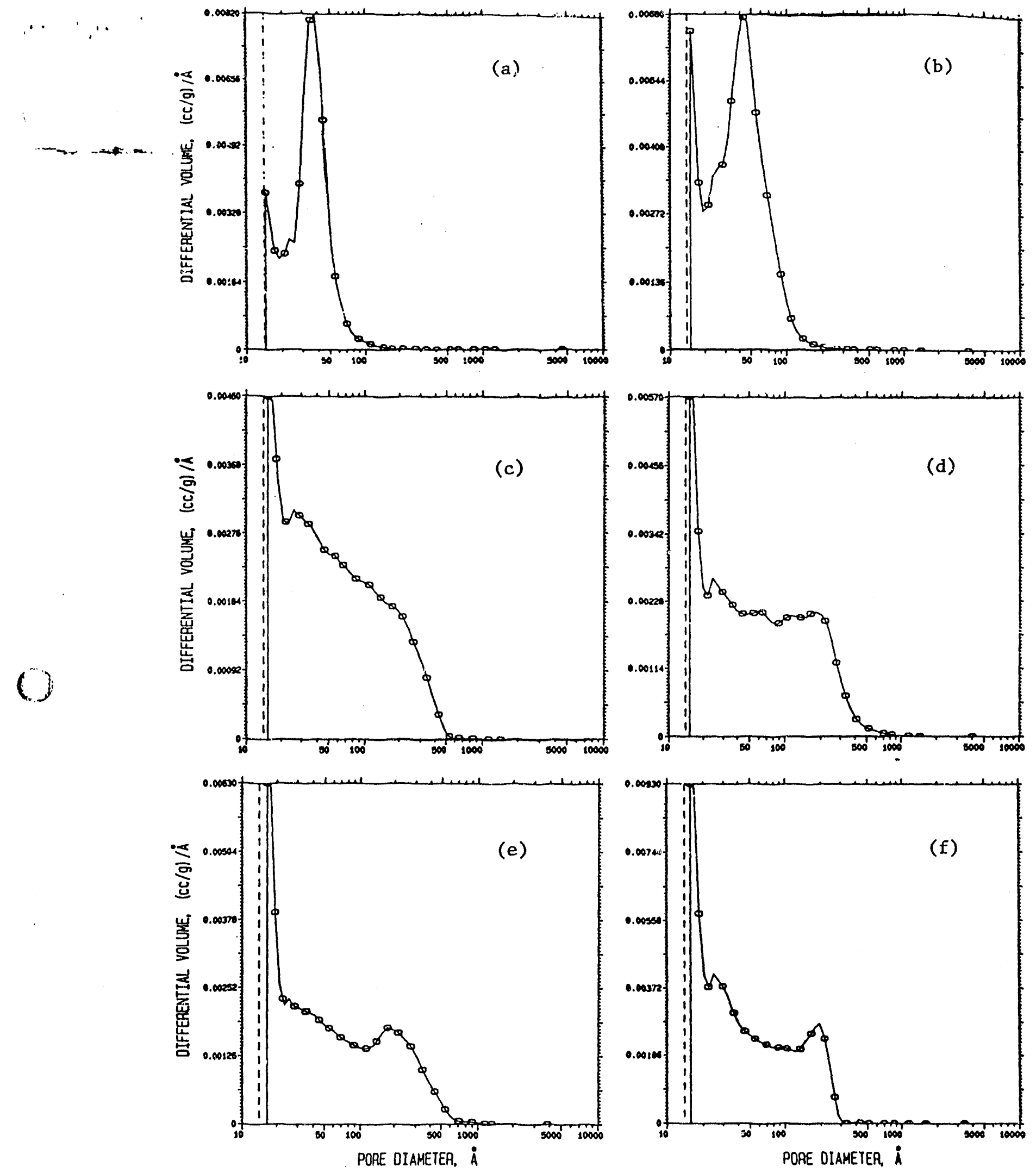

Fig. 3. Differential pore volume distribution of calcined catalyst.
(a) $100 \mathrm{Fe} / 5 \mathrm{Cu} / 4.2 \mathrm{~K}$,
(b) $100 \mathrm{Fe} / 5 \mathrm{Cu} / 4.2 \mathrm{~K} / 8 \mathrm{SiO}_{2}$,
(c) $100 \mathrm{Fe} / 5 \mathrm{Cu} / 4.2 \mathrm{~K} / 16 \mathrm{SiO}_{2}$,
(d) $100 \mathrm{Fe} / 5 \mathrm{Cu} / 4 \mathrm{~K} / 2.4 \mathrm{SiO}_{2}$, (e) $100 \mathrm{Fe} / 5 \mathrm{Cu} / 4.2 \mathrm{~K} / 40 \mathrm{SiO}_{2}$, and (f) Ruhrchemie catalyst $\left(100 \mathrm{Fe} / 5 \mathrm{Cu} / 4 \mathrm{~K} / 25 \mathrm{SiO}_{2}\right)$. 


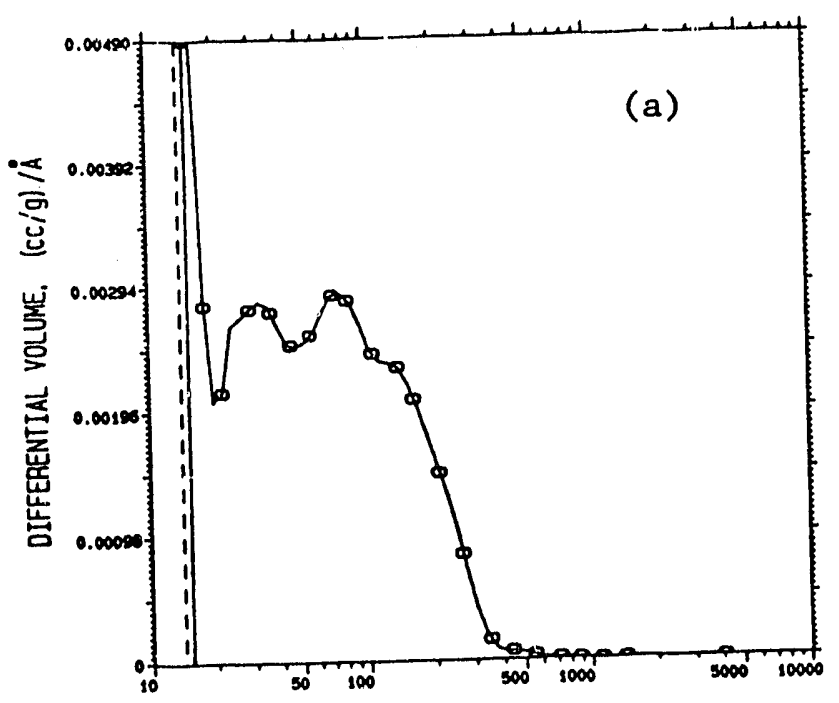

()

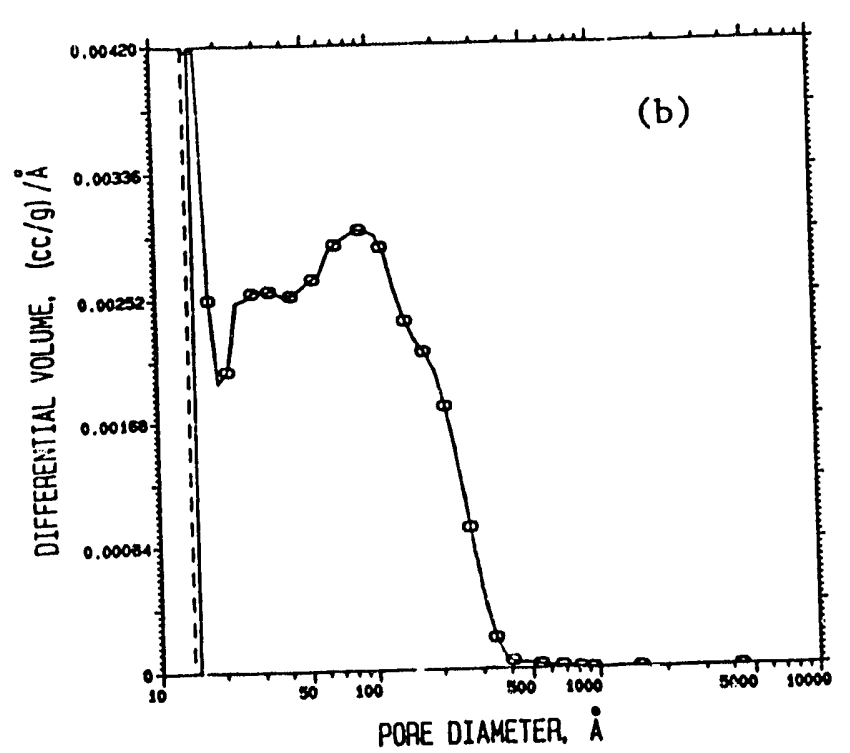

Fig. 4. Differential pore volume distribution
of calcined $100 \mathrm{Fe} / 3 \mathrm{Cu} / 4 \mathrm{~K} / \mathrm{zSiO}_{2}$ catalyst. (a) $z=8$, and (b) $z=16$. 


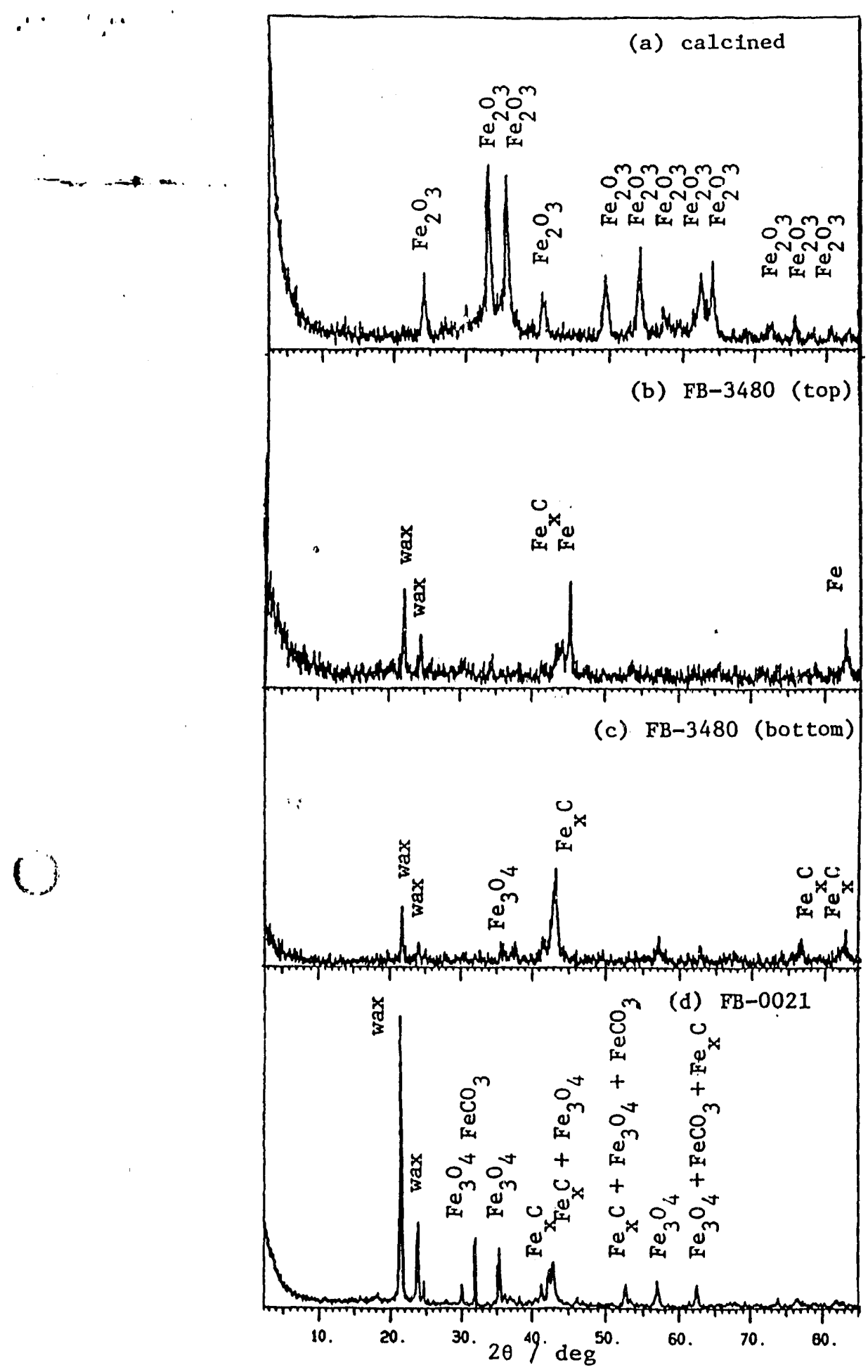

Fig. 5. XRD patterns of $100 \mathrm{Fe} / 0.3 \mathrm{Cu} / 0.8 \mathrm{~K}$ catalyst

(a) after calcination, (b) after reduction with $\mathrm{H}_{2}$ followed by reaction (from the top part of the reactor), (c) after reduction with $\mathrm{H}_{2}$ followed by reaction (from the bottom part of the reactor), and (d) after reduction with $\mathrm{CO}$ followed by reaction. 

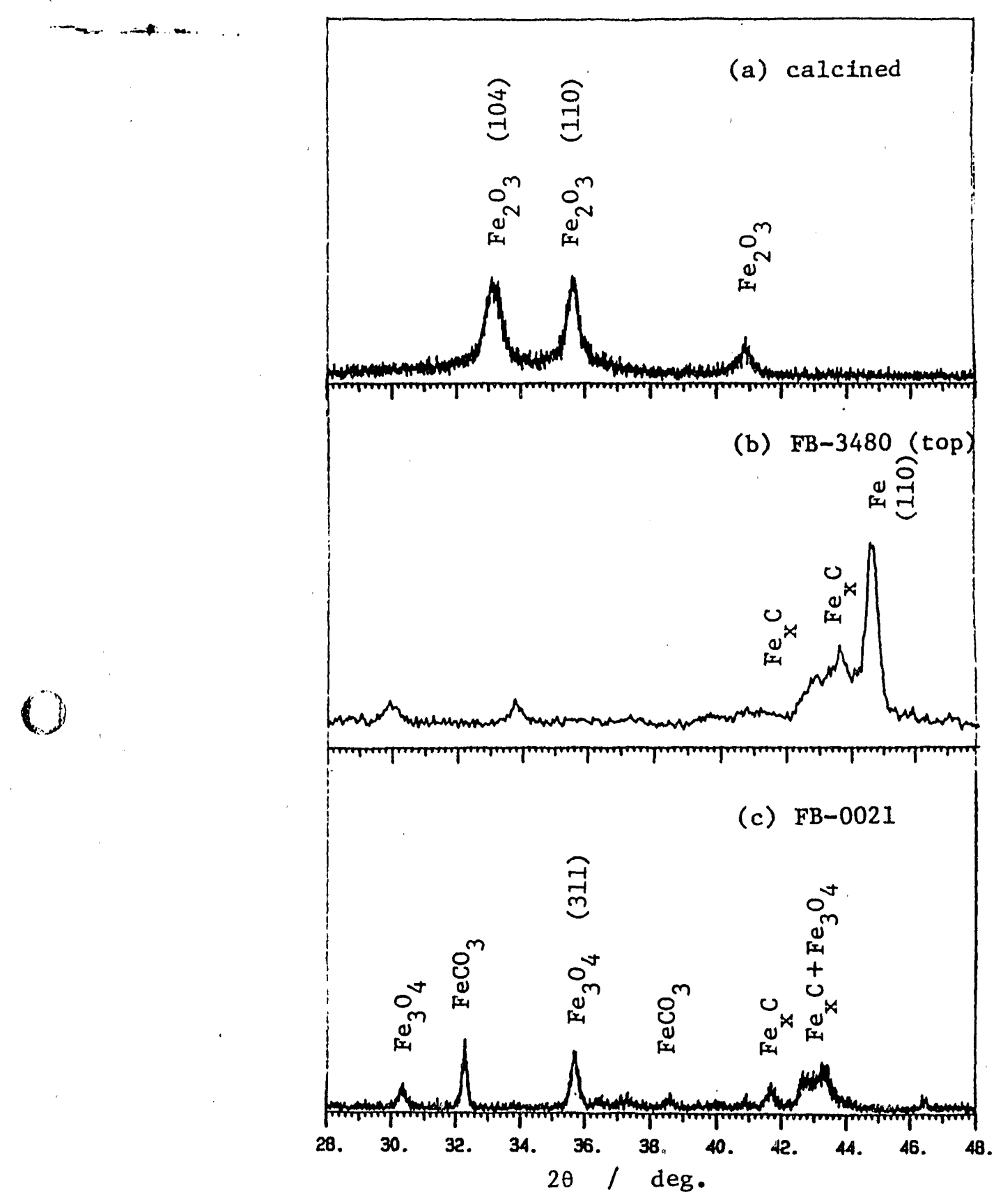

Fig. 6. XRD patterns of $100 \mathrm{Fe} / 0.3 \mathrm{Cu} / 0.8 \mathrm{~K}$ catalyst with slow scan.

(a) after calcination; (b) after reduction with $\mathrm{H}_{2}$, followed by reaction (from top part of the reactor); and (c) after reduction with $\mathrm{CO}$ followed by reaction. 


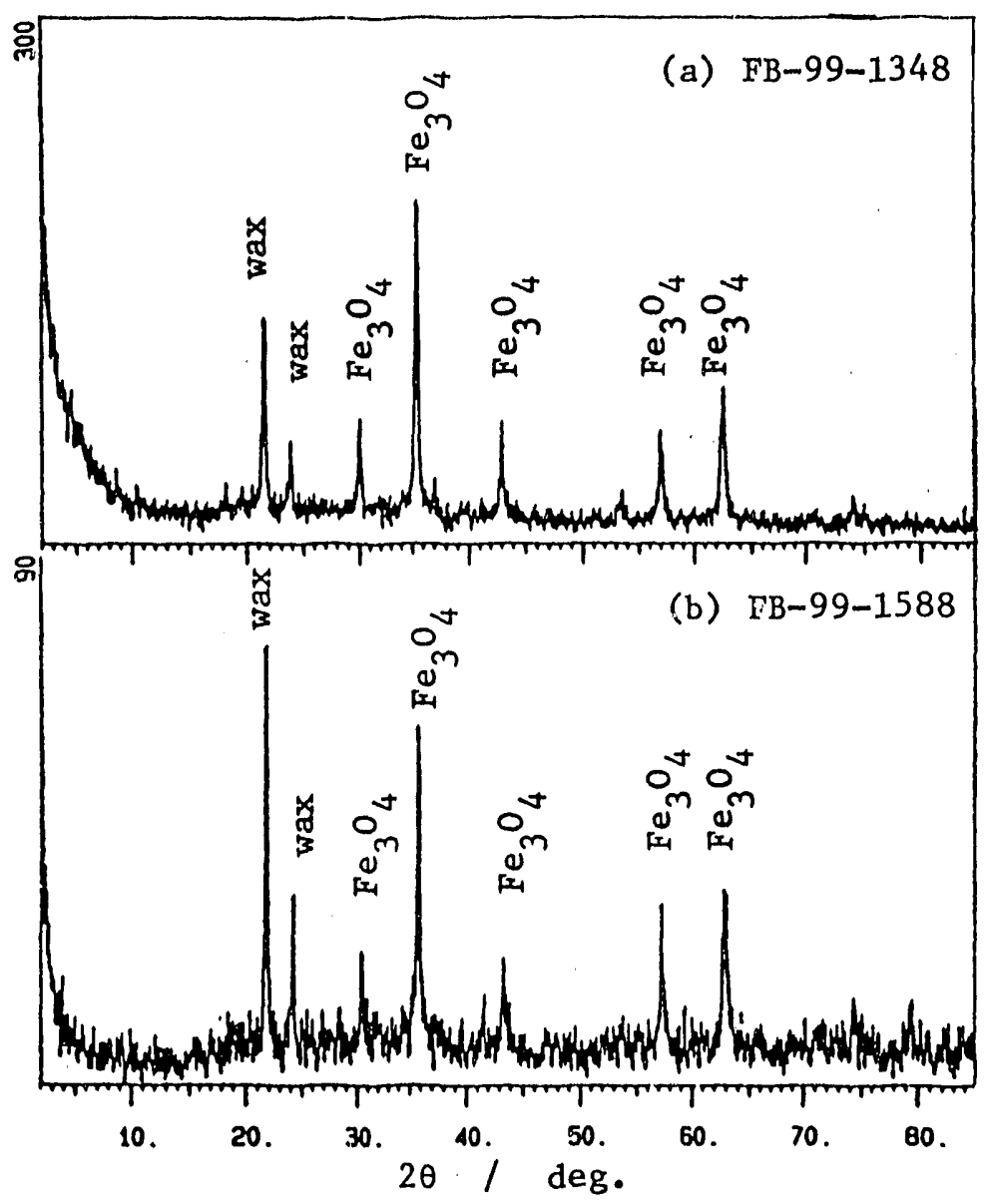

Fig. 7. XRD patterns of used Ruhrchemie catalyst reduced with $\mathrm{CO}$.
(a) $\operatorname{TOS}=169 \mathrm{~h}$, and (b) $\operatorname{TOS}=623 \mathrm{~h}$. 


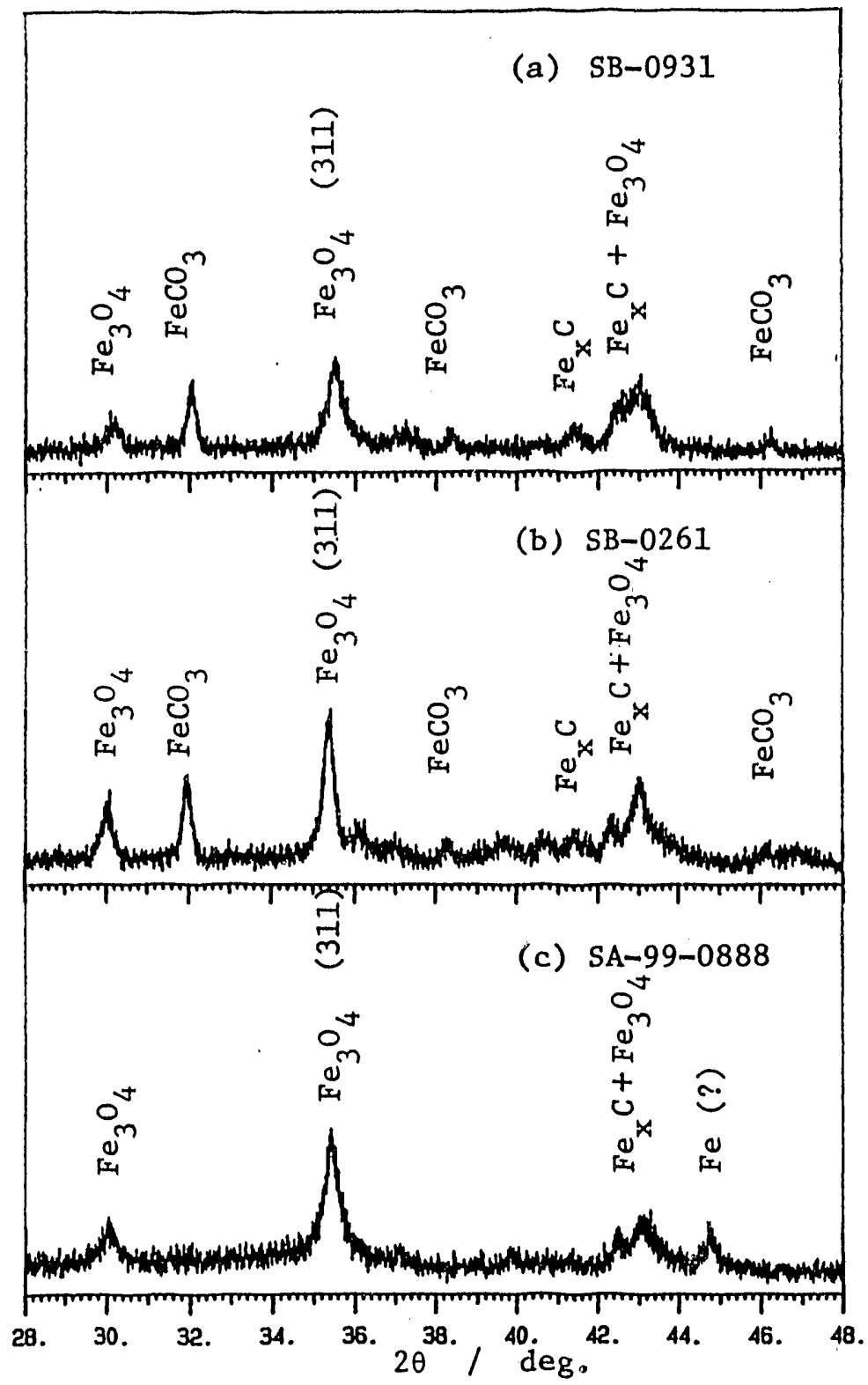

Fig. 8. XRD patterns of used catalyst in slurry reactor.

(a) $100 \mathrm{Fe} / 3 \mathrm{Cu} / 4 \mathrm{~K} / 8 \mathrm{SiO}_{2}$ reduced with $\mathrm{H}_{2}(\mathrm{TOS}=564 \mathrm{~h})$,

(b) $100 \mathrm{Fe} / 3 \mathrm{Cu} / 4 \mathrm{~K} / 16 \mathrm{SiO}_{2}$ reduced with $\mathrm{H}_{2}$ (TOS $\left.=435 \mathrm{~h}\right)$, and

(c) Ruhrchemie catalyst $\left(100 \mathrm{Fe} / 5 \mathrm{Cu} / 4 \mathrm{~K} / 25 \mathrm{SiO}_{2}\right)$ reduced with CO (TOS $=619 \mathrm{~h})$ 。 
2
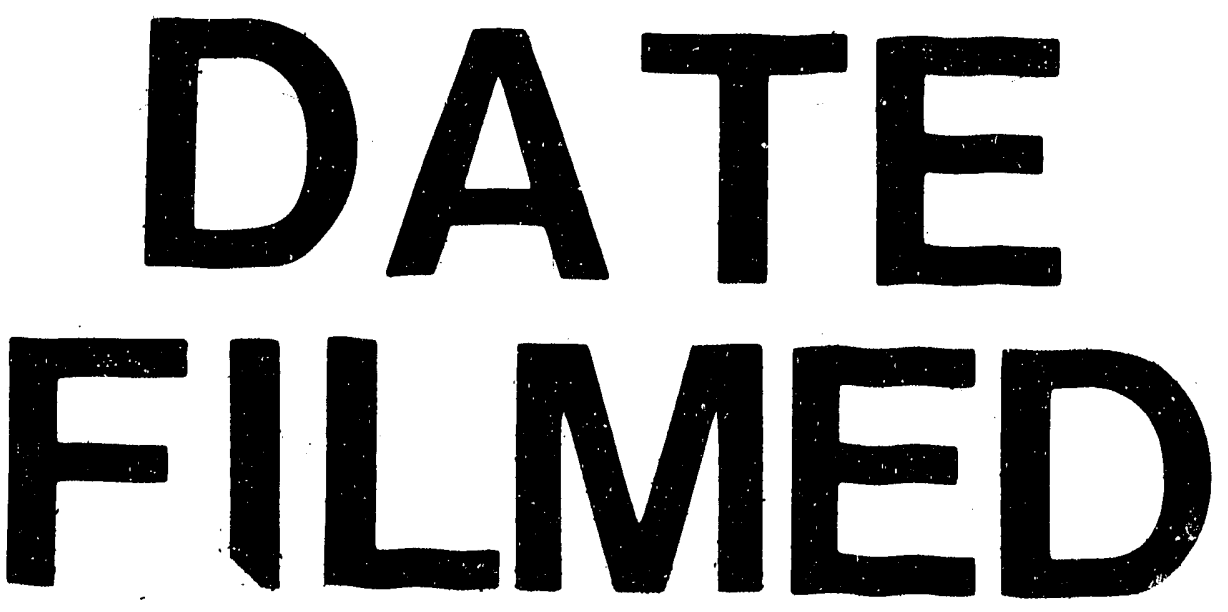

$8 / 17 / 92$

- 